\title{
THE USE OF BAMBOO FIBER IN BABY CLOTHING FROM THE POINT OF SUSTAINABILITY AND LIFE-CYCLE PROCESSES
}

\author{
Dilek TÜM CEBECI ${ }^{1}$
}

${ }^{1}$ Dr. Marmara Üniversity, dilektum(at)marmara.edu.tr, ORCID: 0000-0002-4702-0725

Tüm Cebeci, Dilek. "The use of bamboo fiber in baby clothing from the point of sustainability and life-cycle processes" ulakbilge, 41 (2019 Ekim): s. 703-710. doi: 10.7816/ulakbilge-07-41-02

\begin{abstract}
This work mainly deals with the relation between sustainability and (sustainable) textile product design. The particular interest is on the product life cycles such that a comprehensive investigation is made for ecologically viable textile products. The discussion of processes associated with the product life cycles is made from the ecological point of view. A particular investigation is made to exhibit the advantages of the use of bamboo as an eco-fiber. Specifically, the work focuses on some bamboo-made textile products in baby clothing. Finally, lifecycle processes for a bamboo-made baby clothing are illustrated.
\end{abstract}

Keywords: Sustainability, eco-design, ecological fibers, life-cycle processes 


\section{Introduction}

Conceptually, the term "sustainability" possesses three fundamental meanings. In its original use in forestry science in late 1713 by forestry expert Hans Carl von Carlowitz, it gets its meaning as a concept of harvesting only the amount of timber that regrows in the same region as well as at the same period of time in a year. In its second and today's use, the sustainability is considered to be a persistent effect in designing a product. In its third main context, the sustainability is seen as a generic principle that restricts the use of resources to a level that is available by reproductive means.

In its use in textile design, the sustainable textiles have a wide range of use and application. In clothing industry, the sustainability corresponds to fabrics produced from eco-friendly resources such as sustainability grown fiber crops or recycled materials such as organic cotton, bamboo, hemp etc. In the light of these considerations, social, environmental and economic effects can be seen as three important pillors in sustainability concept (Cavagnaro and Curiel, 2012: 15-17)

Moreover, some people consider that the sustainability is a balance established by environmental, social and economical factors. In this sense, sustainability gains importance in designing eco-friendly products in textile industry. Therefore, it is closely related with the concept of ecological textiles. In this respect, ecological design processes are seen to be crucial in the design of eco-textile products (Gardetti and Torres, 2013: 1-20)

Ecological design mainly includes and requires a complete review and analysis of world energy resources including the efficient use of the natural resources such as organic fibers found in nature. Integration of textile machinery and tools into an efficient system of production also becomes important. There are some textile companies that use several ecological design methods to set up the future of the textile industry into an ecofriendly or environmentally viable one. In connection with the ecological textile production, the efficient use of natural resources may require recycling of clothings therefore minimizing the use of resources. It also requires using biodegradable textile materials to reduce the impact on the environment, and using plant dyes instead of poisonous chemicals to improve the appearance of fabric.

In association with sustainability concept, there has been also a wide interest on life cycles and processes associated with those. Together with the concept of sustainability in ecological textile industry, life cycle processes are also crucial in designing and producing eco-friendly clothes in textile life (Blackborn, 2009: 3-5; Cepolina, 2012: 7-13; Göndör and Pataki 2008: 19-28) In accordance with the ecological design of textile products, recycling process in textile products is discussed in (Wang, 2006: 32 )The use of concept of sustainability in fashion industry is also investigated in (Fletcher, 2008: 12-14)

In this work, in the first part the life cycle processes for a textile product are presented. Some processes are briefly explained in a view to conform with the ecological textile concept. Next, the use of bamboo fibers in the infant clothing is examined. In a view closely related with ecological textiles, the advantages and importance of using bamboo fibers in infant clothing are emphasized. Finally, we conclude with some comments.

\section{Life cycle processes for a textile product}

We believe that, for ecological reasons, the design of a textile product for a full life cycle is very important though it is not extensively adapted by many textile companies. Many textile designers still use the conventional methods in designing a product. However, these methods can put some restrictions on the demands concerning a textile product.

Below, possible phases of a life cycle are presented for a textile product. However, it should be kept in mind that a textile product can meet much less of the demands of customers at the end of a life cycle and as a result of that the product may become outdated. In this respect, a modern design process should take into consideration almost all the demands in a way that it will also be an eco-friendly product. To clarify the processes, first the ecodesign of the textile product should be realized. Next, eco-fiber production should be made. Then the processes continue with harvesting and production cleaning of the fibers. Next, spinning process of the yarn should be realized. Then, the fabric production is started. And then finishing processes for the fabric should be done. As a next stage, garment manufacturing is made. Garment manufacturing is followed by packaging, transportation and distribution of the textile product. Then it goes into the consumer use. After the consumer use, the textile product 
may go into three different stages. It can be reused or it can go into disposal without entering recycling process. Or as can be seen from the chart, it can again go into a recycling process in a way to support the view of an ecological textile production.

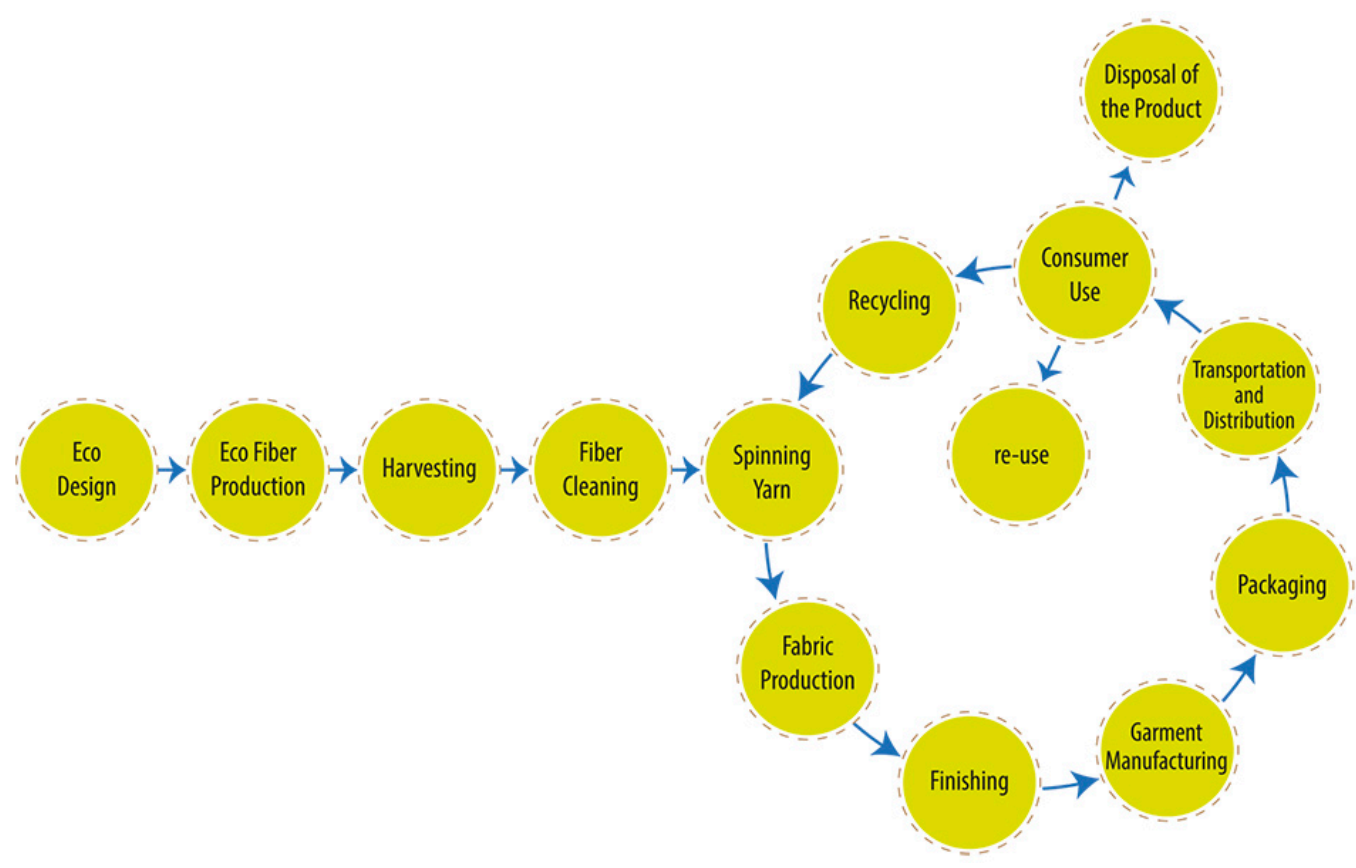

Figure 1 : Life cycle processes for a general textile product

Below, we briefly explain some processes from the ecological point of view. We mainly discuss how the processes should be realized in order that an ecologically viable product is produced.

\section{Eco-design:}

Eco-design is considered to be an approach to design of a textile product taking the environmental impacts of the product throughout its life cycle into account. It is a crucial approach for the production of an ecologically viable textile product. Therefore, eco-design is the starting point of producing an eco-friendly clothing.

\section{Eco-fiber production:}

For an ecological textile production, the use of eco-fibers is of crucial importance. The most commonly used eco-fibers include organic cotton, bamboo, wool, soy cashmere, silk. Moreover, fiber production should be made in accordance with the GOTS (Global organic textile standards) certificate.

\section{Harvesting:}

From the ecological point of view, the use of chemical pesticides and fertilizer should be avoided as much as possible. Moreover, the use of fuel-powered machinery should be also reduced during harvesting. It can be expected that this prevents air pollution to some extent. Instead, harvesting of the fibers by conventional methods should be encouraged.

\section{Fiber cleaning:}

In most of the fiber cleaning processes, the use of strong chemicals is essential, so it has dangerous effects on the human health and the environment. As is well-known, some of these chemicals emit volatile organic compounds causing respiratory, dermatological disorders on human health. In this sense, the use of chemically reactive and toxic products that may contain various toxic chemicals should be avoided. 


\section{Spinning yarn:}

During spinning of the fiber yarn, sudden jerks should not be permitted since the fibers can suffer from forming scraps and hence wastes. For an eco-friendly process, the spinning should be realized in an environment having a suitable temperature and moisture thereby reducing the eco-fiber loss.

\section{Fabric production:}

For the eco-fabric production, weaving of a fabric should be accomplished according to OEKO-TEX 100 standards. Mainly, OEKO-TEX ${ }^{\circledR}$ Standard 100 is an independent test and certification system that is used at all stages of processing and production of textile raw, intermediate and end products.

The main characteristics of the OEKO-TEX 100 standard is that the tests that it requires, should contain the knowledge of parameters which are crucial for human health, namely the knowledge of substances that should be banned or controlled and also the knowledge of harmful chemicals.

\section{Finishing:}

In textile world, finishing corresponds to the union of the processes that convert the fabric into a usable material. To be specific, it corresponds to any process performed after dyeing the fabric to improve its look and performance.

During finishing processes, for ecological reasons, it is essential to reduce especially the use of toxic byproducts. It is also important to minimize the use of chemicals such as potassium permanganate, sodium hydroxide etc., since these chemicals tend to appear in high concentrations with a high Ph-level. The water and energy consumption should also be reduced as far as possible. As a result, this minimizes the aqueous waste leading to a more ecological life. To sum up, all the equipment used during finishing processes should have an environmental policy.

\section{Garment manufacturing:}

In garment production, cutting and sewing of the fabric should be performed uniformly and efficiently as possible to minimize the fabric waste. Also, intermediate processes like ironing and quality control processes should be realized according to ecologically acceptable standards such as GOTS (Global organic textile standards).

\section{Packaging:}

For ecological reasons, the material used for packaging should not contain polyninyl chloride (or shortly PVC) substance. Instead, recyclable materials (such as milk cartons and paper-made bags) can be used for packaging.

\section{The use of bamboo fiber in infant clothing}

In this part, we briefly introduce the bamboo as an ecological fiber and examine the advantages of using that fiber in textile products. The importance and the role of bamboo in its use in textile products are also discussed in (Waite, 2009: 1-21; Waite 2010: 1-22) As a specific application of the bamboo use, we also present some samples from infant clothing produced from bamboo fiber and briefly illustrate the advantages of using bamboo in infant clothing.

Bamboo fibre is known as cellulose-based natural textile fiber produced from the pulp of the bamboo plant. Since the bamboo grows without use of pesticides and chemical fertilizers, it has been popular as an ecological (or organic) fiber. Therefore, it is also known as "the green fibre". It is also claimed that bamboo is more sustainable compared to most of the other fibers such as cotton, hemp etc. The figure 2 below shows the view of a bamboo plant. 


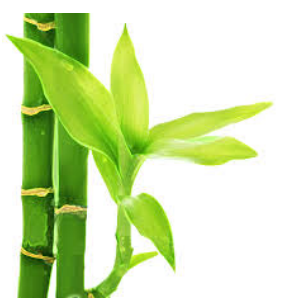

Figure 2: The view of bamboo plant

Bamboo is known to be extremely resilient and durable as a fiber. In some studies examining and comparing it with respect to cotton and polyester, it has been observed that it has a high tenacity-preventing property, in addition to a better moisture-wicking and a better moisture-absorbing qualifications. Figure 3 briefly shows some processes associated with bamboo fiber from its harvesting as a plant to its realization as a bamboo fabric.

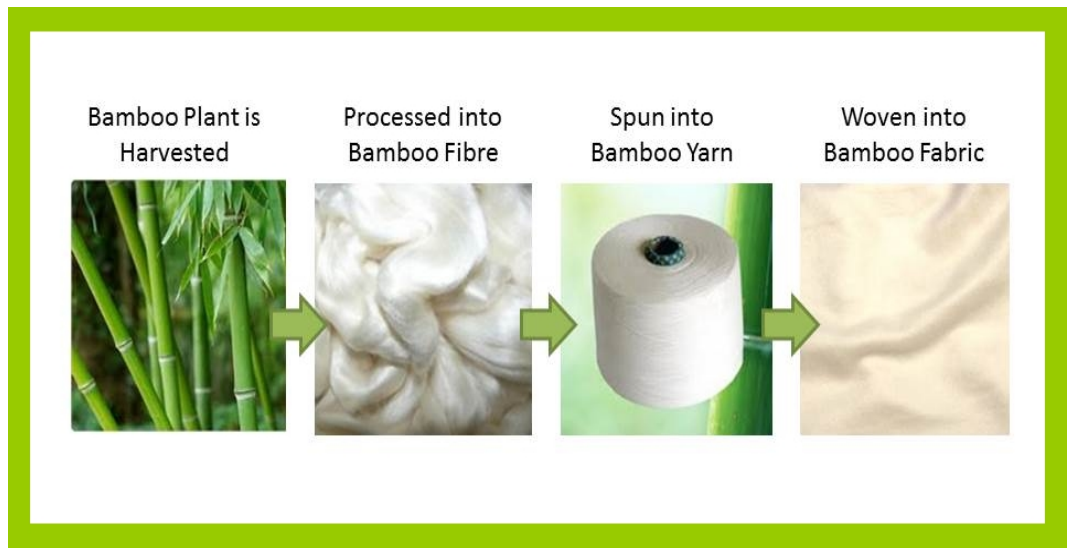

Figure 3 : Some processes associated with bamboo fiber

Now, we present some ecological reasons for using bamboo as a raw material for textiles and clothing :

First of all, bamboo has a high growing rate. Also, it can grow in diverse regions having different climates so that it becomes a sustainable resource for any textile product. Moreover, bamboo grows rapidly and naturally without any need for use of pesticides, herbicides and fertilizers so that it becomes an eco-friendly fiber. Secondly, growing bamboo improves the soil quality. It holds soil together so that it may prevent soil erosion.

Next, the bamboo can also be re-harvested without any damage to environment. The plant has a regenerative property such that it regenerates after being cut without need for re-planting. Harvesting of bamboo can also be done without use of any chemicals making the bamboo more ecological compared to others.

In addition to benefits of using bamboo, it should be stated that the bamboo minimizes the carbondioxide rate while producing $35 \%$ more oxygen than an equivalent stand of other trees. As another crucial advantage, the bamboo plant can reduce deforestation. It also needs less-irrigation when compared to cotton.

As a natural cellulose fiber, bamboo is also known to be biodegradable textile substance. It can be biodegraded in soil by microorganisms and sunlight with $100 \%$ percentage making the bamboo-made clothing more effectively recyclable compared to other fibers. Moreover, this decomposition process does not lead to any pollution in the environment making again the bamboo fiber more ecological than others.

Next, to mention some of the advantages of the fabric made from bamboo fiber, it has been observed that the bamboo fabric is strong and light. It has excellent wicking properties. Moreover, bamboo fibers and fabrics made from them can be said to absorb dye faster and more effectively compared to other fibres such as cotton. As a further advantage of using bamboo fibers, we should add that unlike cotton, bamboo-made fabrics do not require 
to be mercerized to improve their luster and dye-ability.

It is also anti-bacterial to some extent making the bamboo clothing ideal for infant clothing. The infants using other natural fibers (such as hemp, wool etc.) can complain the issue of allergic reactions. On the other hand, the babies (or even people) wearing bamboo-made cloths do not suffer much from such type of allergic reactions. Its high wicking property and its lightness also make the bamboo-made infant cloths ideal. In figures 4,5 and 6 , some bamboo-made textile products are exhibited.

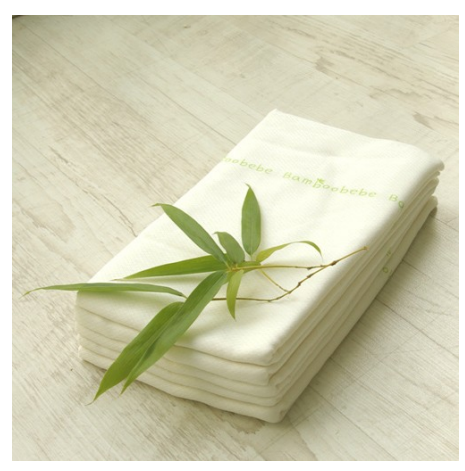

Figure 4 : Baby towel

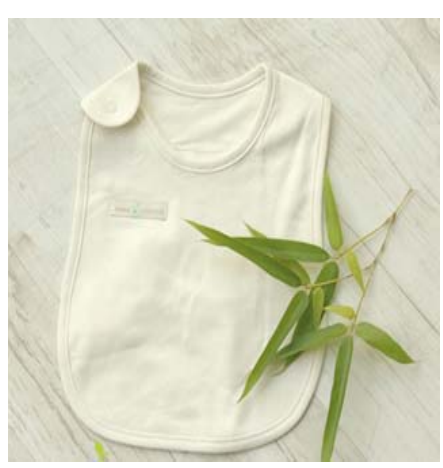

Figure 5 : Baby pinafore

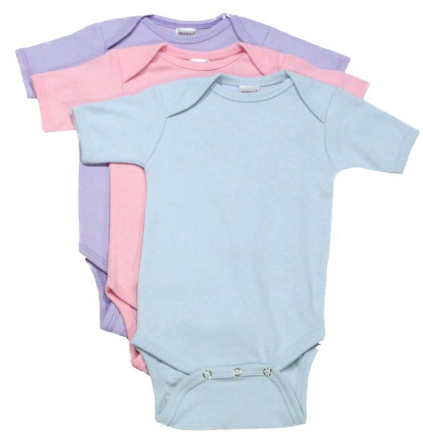

Figure 6 : Baby clothing

Finally, it is also of interest to analyze the life cycle processes for a bamboo-made cloth. In figure 7 below, we present such a cycle for an infant clothing. The cycle is similar to life-cycle for a generic textile product except that the use of bamboo-fiber in a daily-use infant clothing is emphasized.

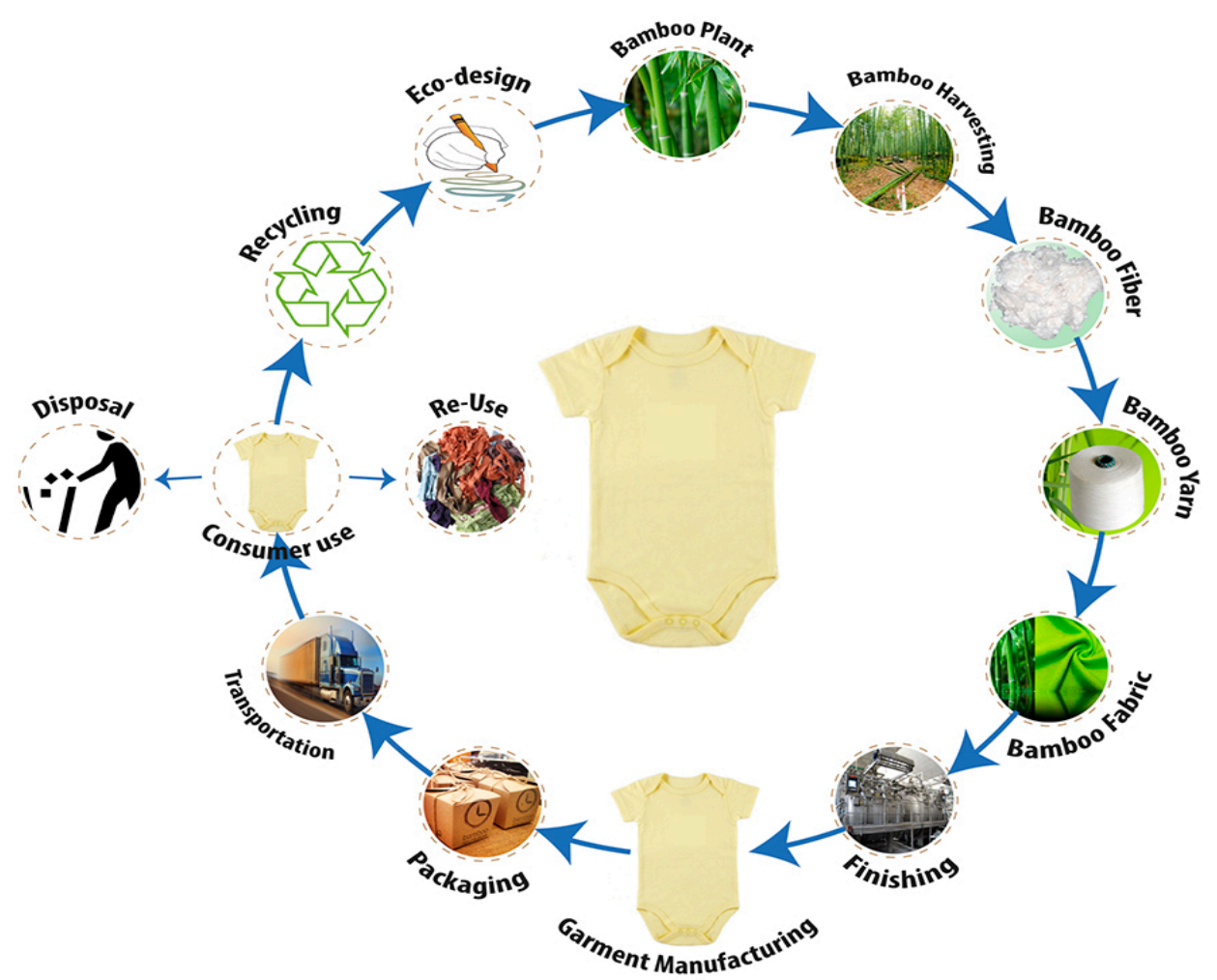

Figure 7 : Life cycle processes of a bamboo-made infant clothing 


\section{Conclusion}

In this work, we have mainly investigated the life-cycle processes for a sustainable (or ecologically viable) textile product. We have presented and briefly explained some of the life-cycle processes from the ecological point of view. Next, we have particularly concentrated on the advantages of using bamboo fiber in design and production of a textile product. We have exhibited the properties of bamboo fibers. We have emphasized that due to its property of being biodegradable, bamboo-made products can go recycling process more effectively compared to other fibres such as cotton, hemp etc. Next, we have presented some bamboo-made textile products for infants. Also, we have briefly mentioned the importance of using bamboo fibers in infant clothing. We have particularly illustrated that due to its property of being anti-bacterial, its lightness and having high wicking property, the bamboo-made textile products are ideal for the use in infants.

In the light of comments and explanations made in the text, we believe that the use of ecological fibers in textile industry should be encouraged. Awarness and consciousness of the people towards using ecological and recyclable products should be increased. New textile standards having improved eco-labels should be introduced. Especially, owing to invaluable advantages of using bamboo fiber as an ecological and recyclable one, the use of that fiber in textile products should be raised.

\section{References}

Blackburn, R. S. (2009). Sustainable Textiles: Life Cycle and Environmental Impact, Cambridge: Woodheart Publishing Ltd.

Cavagnaro, E. , Curiel G. (2012). The Three Levels of Sustainability, UK: Greenleaf Publishing

Cepolina, S.E. (2012). Textile and Clothing Industry: An Approach towards Sustainable Life Cycle Production, İnternational journal of Trade, Economics and Finance, Vol. 3, No.1

Fletcher, K. (2008). Sustainable Fashion and Textiles, London UK: Earthscan Publishing,

Gardetti, M.A. , Torres, A.L. (2013). UK: Sustainability in Fashion and Textiles, (Values, Design, Production and Consumption) Greenleaf Publishing Limited, Sheffield

Göndör, V. , Pataki, M. (2008). Designing Textile Products for the Full Life Cycle with a special focus on Maintenance During Usage, Acta Polytechnica Hungarica, Vol. 5, No. 3

Wang, Y., Y., (2006). Recyling in Textiles, Cambridge UK: Woodhead Publishing Limited The Textile Institute.

Waite, M. , (2009). Sustainable Textiles: The Role of Bamboo and Comparison of Bamboo Textile Properties, Journal of Textile and Apparel, Technology and Management (JTATM), Vol. 6, İssue 2

Waite, M. , (2010). Sustainable Textiles: The Role of Bamboo and Comparison of Bamboo Textile Properties (Part II), Journal of Textile and Apparel, Technology and Management (JTATM), Vol. 6, İssue 3 


\section{Ulakbilge}

\section{SÜRDÜRÜLEBILİRLIKK AÇISINDAN BEBEK GIYIMIINDE BAMBU LIFİ KULLANIMI VE YAŞAM DÖNGÜ ISSLEMLERI}

\section{Dilek TÜM CEBECİ}

$\ddot{O} z$

$\mathrm{Bu}$ çalışma temel olarak sürdürülebilirlik ve (sürdürülebilir) tekstil ürünü tasarımı arasındaki ilişkiyi ele almaktadır. Özel odak noktası ürün yaşam döngüleri üzerine olup ayrıntılı inceleme ekolojik anlamda tasarlanmış tekstil ürünleri üzerine yapılmıştır. Ürün yaşam döngüleri ile alakalı işlemlerin tartışması ekolojik bakış açısıyla vurgulamıştır. Özel olarak, bir ekolojik lif olarak bambu kullanımının faydalarını ortaya çıkarmak için inceleme yapılmıştır. Çalı̧̧mada ayrıca, bebek giyiminde bambudan yapılmış tekstil ürünleri üzerine odaklanılmıştır. Sonuç olarak, bambudan üretilmiş bebek kıyafetleri için yaşam döngü işlemleri sunulmuştur.

Keywords: Sürdürülebilirlik, eko-tasarım, ekolojik lifler, yaşam döngü işlemleri 